\title{
Exploring the character of rural businesses: Performing change and continuity
}

\begin{abstract}
The purpose of this paper is to use a series of business interviews in the UK and Denmark as a means of interrogating the categorisation of rural businesses presented in an earlier publication which sought to understand the rural character of different businesses (Bosworth 2012). Rather than defining a rural business purely on its geographical location, the engagement of a business within a rural economy and its relations with both rural and urban environments are more complex issues. A wider conceptualisation how rural social relations, cultural influences and landscape values, forms the basis for analysing how these assets can create value for rural businesses. Understanding these issues can better inform organisations that are seeking to support the rural economy and rural communities. It can also guide business owners themselves as to how they might benefit from being a part of, or associated with, the rural economy in capturing the possibilities linked to a growing urban population. The findings reveal how landscape assets are intertwined in the business concepts as positive drivers despite many voices within rural and economic research pointing at disadvantages relating to distance, sparseness of infrastructure or service provision. The research analysis draws on Actor-network theory and this tool reveals promising prospects for future placebased studies in how landscape assets can be enacted in the development of the rural economy.
\end{abstract}

\section{Keywords}

Rural Economy, rural businesses, rural change, landscapes values

\section{Introduction}

Rural places are continuingly shaped and re-shaped by the economic activities taking place within them, be they economic, recreational or residential (Antrop, 2005; Claval, 2005). Rural places and local landscapes are highly intertwined as assemblages of heterogeneous elements: farmlands, woods, gardens, grassland, mountains, hiking trails, lakes, roads, villages, animals and people. Relating to community and landscape assets, this paper seeks to offer a deeper understanding of the different practices of different types of rural businesses, the barriers and opportunities that they face and the implications for local rural development.

A series of business interviews in the UK and Denmark are used as a means of interrogating an earlier categorisation of rural businesses where location alone was considered an inadequate parameter for defining a "rural business" (Bosworth 2012). Additional characteristics such as their embeddedness within local areas and the diversity of connections with rural landscapes are considered to be important for understanding how rural places are re-shaped by, and influence the performance of, rural business activities. This perspective has recently been reinforced in a policy note from the CLA (2016), a membership organisation for owners of land, property and business in rural England and Wales, which asserts that there is "something intrinsically different" about rural businesses. Similar trends are identified in Denmark, where a large number of municipal strategic plans for rural areas focus on the facilitation of alternative economic initiatives supported by various landscape values such 
as accessibility to farmland, openness, health issues and remoteness. Thus, our working research question is "how do rural businesses draw on community-based and landscape assets to sustain their everyday practices and performance?"

In order to enrich our understanding of how landscapes and rural places are enacted in the interplay with new business practices, we apply tools from Actor-Network Theory (ANT). This approach, first manifested through the book We have never been modern by Latour (1993), (and further developed into many different strands within human and economic geography) allows us to unfold how not only humans but also non-humans (eg. landscapes, villages, policies) can be assigned with agency. This is crucial to describe and discuss the sometimes unexpected effects of rural business developments as well as the material or discursive relations, that make them stable or make them fall apart. Within the existing policy and research paradigm, landscape values are most often perceived as amenities, ecosystem services or public goods, which leaves them outside the focus of the way they a produced or maintained, namely by the economic activities taking place in the countryside.

Understanding the nature of a "rural business" is equally contested. Figure 1 illustrates an earlier attempt to stimulate debate in this area (Bosworth, 2012), suggesting that a rural business must satisfy at least two of the criteria illustrated. Additionally, the connection with the local landscape could be integrated into a deeper understanding of what makes a business "rural" in character (Finke, 2014) while other criteria such as the value of rural social relations and networks (Moyes et al., 2015) or the employment of local people might also be relevant.

\section{INSERT FIGURE 1 NEAR HERE}

\section{Interrogating Rural-ness}

Although small businesses were found by some to have suffered disproportionately during the recession (Chow and Dunkelberg, 2011, cited in Moyes et al., 2015), other research has shown that, despite, or perhaps because of, the predominance of smaller businesses in rural areas, rural businesses were more resilient during the economic crisis (Anderson et al., 2010). The prevailing rhetoric of rural disadvantage in economic and business literature, is characterised by sparse networks, peripherality, remoteness and a general lack of service provision which constitutes a "rural penalty" (Malecki, 2003; Bell, 2010). Instead, we argue that a deeper understanding of the effects of "rural-ness" for small businesses, particular those exhibited through rural landscape values, can inform new research agendas, practices and policy in this field.

Definitions of rurality and how to support the rural economy have been challenging themes among scholars from different academic fields as well within European policy and planning for at least the last two decades (Bosworth and Somerville 2013; Cloke, 2006 \& 2015; Halfacree, 1993). As Woods (2011) notes, the term 'rural' encompasses everything outside the urban sphere and therefore attracts attention across many different research disciplines. Complex rural-urban interrelations increase the challenges of understanding the contemporary rural economy, particularly where rural businesses rely on these interconnections for many new demands for nature experiences, health services, tourism activities and products with rural brands (Ploeg and Marsden, 2008). This is reflected in new business activities emerging from both agricultural and rural business diversification as well as from urbanites attracted or returning to rural environments where they can employ their 
entrepreneurial capabilities to draw on rural landscape assets in new businesses (Finke, 2014). Such changes in the rural economy raise questions about what distinguishes the ex-urbanite, the diversifying farmer or the indigenous village shopkeeper in terms of their business activities and their rural-ness or urban-ness.

Questions also emerge about their engagement and interaction with the local community and countryside as a process in the creation of new possibilities through which the re-valorisation of local landscapes emerge. This calls for a re-interpretation of the rural, where unforeseen phenomena are identified without any a priori assumptions of 'authenticity' or aspects of the 'rural idyll' as the basic ideas of what constitute the assets of a rural space. The meaning of local landscape heritage is also constantly re-produced (Braaksma et al., 2016) through different appreciations of landscape aspects and new rural practices. Hence, our key contention here is, that questions of the 'authenticity' as well as the notion of 'identity' are not constructive in capturing the ongoing changes, as those concepts tend to assign the rural places with a certain stable image of rurality excluding the factors that produce the changes.

This blurring of what is 'rural' and what is 'urban' divides opinions between scholars; some see newcomers' aesthetically-motivated and entrepreneurial actions as "violating the rural" (Vasiliki, 2013) while other, arguably more progressive voices, focus on the rural power related to intangible and symbolic values as part of the interdependency that shapes today's rural-urban reality (Cook et al., 2004). Structural definitions of rurality form the basis for economic and broader rural development policies under the New Rural Paradigm (OECD, 2006) where the countryside has shifted from a space of pure production to a multifunctional space (Mitchell, 2013). Drawing on Schumpeter's notion of creative destruction, Mitchell (2013) sees the new functions of landscape within the multifunctional paradigm as part of a "creative enhancement" that builds upon previous landscape uses rather than over-riding them completely.

Compared to the urban lifestyle, landscape values form a more predominant part of the rural environment, but both natural and built environments play a role in shaping local cultural identities (Antrop, 2005; Claval, 2005). Despite the symbiotic association between rural communities and rural economies, cultural factors related to local behaviour and place-based development are often absent in the analysis of economic change and development (Huggins and Thompson, 2015). It could be argued that the increasingly consumption-led drivers of the rural economy (Slee, 2005) include desires to consume features of rural communities and rural landscapes - whether directly through being in these landscapes or indirectly through the consumption of products represented of or bounded to symbolic values of rural places (Bell et al., 2010). Rural landscapes carry romantic or subjective memories (Cloke and Jones, 2001; Antrop, 2005) of the past, yet they are simultaneously spaces of continuous development. Recent contributions to the development of conceptual frameworks for practice driven rural research, suggest the landscape as the point of departure when studying the rural transitions taking place all over Europe (Pinto-Correia \& Kristensen, 2013). Thus, the role of the landscape as a local community asset, and the impacts upon the physical landscape relating to rural economic changes demand greater attention, in particular how the landscape asset forms can enhance rural entrepreneurial opportunities.

With the composition of rural economies increasingly mirroring those of more urban areas (DEFRA, 2015), traditional sectoral distinctions are less useful. Instead, literature has focused on rural businesses as being smaller (Galloway and Mochrie, 2006) and more sparsely located, thus 
emphasising problems such as the need for technology to overcome peripherality (Salemink et al., 2015; North and Smallbone, 2006), the thinness of local labour markets (Anderson et al., 2010; North and Smallbone, 2006) and the fragility of rural networks and supply chains (Newbery et al., 2013). In the light of some rural regions being more economically resilient in the past recession (McCann et al., 2014), a more positive categorisation that seeks to identify how rural businesses generate social and cultural as well as economic value for their local communities through the employment of local assets could spark new approaches towards rural development strategies on different levels. Furthermore, as suggested by Korsgaard et al. (2015) there should be a differentiation of what is 'rural entrepreneurship' and 'entrepreneurship in the rural', as to support and acknowledge the latter form with the nature of being smaller non-growth-businesses as they engage with local resources in a broad sense in re-enacting local places.

\section{Methodology}

For a better understanding of the ways in which rural businesses engage with and interact with landscape assets, six cases of rural entrepreneurs in England and Denmark form the basis of this study. Three business cases demonstrating particular connections with their local landscapes were drawn from a larger study on Funen (Denmark) and these were matched with three further cases in Lincolnshire (UK) due to the prima facie similarity of their business activities. Semi-structured interviews were carried out along with walking tours through the physical environment of the business. The six interviews were transcribed and further sketched into visual forms, identifying the actor-relations involved in each case. This enabled analysis of the networks of relations and the role of community and landscape assets as co-producers within the business practices.

Lincolnshire and Funen are both considered rural regions within their respective countries, each having just one major city: Lincoln is 120 kilometres from London while Odense (Funen) is $175 \mathrm{~km}$ from Copenhagen. Funen is often referred to as "Denmark's Garden", while Lincolnshire has been described as the "bread basket of England". Hence, the rural representation of the contexts mirrors strongly the production landscapes, and for that reason the cases are chosen in order to identify how landscape values beyond the production aspects associated with agribusinesses co-exist with emerging business types. Some striking similarities between the landscapes of Funen and Lincolnshire, namely the spatial dividing of fields with hedgerows, few woodlands, small villages and highly cultivated hilly landscapes form an immediate impression of being in a "rural" setting.

We apply Actor-Network Theory (ANT) as a method to investigate human and non-human relations within the business-pairs. ANT assumes an ontological worldview without any distinction between nature and society; "For each state of Nature, there exists a corresponding state of Society" (Latour, 1993; 94-95). Thus, trying to unfold connections between non-humans like landscapes, the notion of rurality, business development and humans (communities, new entrepreneurs) ANT is a powerful tool to grasp this complexity (Allen, 2011). ANT is thus a method that helps us to unravel, unfold and describe the detailed webs of relations through empirical case studies that follow. Inspired by the ANT proposition that non-humans as well as humans have agency, we have applied the perspective that landscapes (and other non-humans) can be actors, whose effects operate in conjunction with actions of other social and economic actors. As Mol (2010; 255) explains," An actor acts. It, she, he does something, makes a difference. If the actor were eliminated from its setting, it would take others 
a lot of work to replace these actions". Following this concept, the role and impact of the rural landscapes are the scope of analysis. Hence, if we accept, that the landscapes can make a change, they are productive and therefore shouldn't be seen as merely externalities. One of the founders of ANT explain this as "Economists invented the notion of externality to denote all the connections, relations and effects which agents do not take into account in their calculations when entering into a market transaction" (Callon, 1999; 187). This is useful in order to explore the agency of the landscapes and communities beyond definitions of public goods or 'community capitals' as these can contribute to valuable difference for the business development and rural economy more generally. Essentially, this means, that if neither the landscapes nor the 'community capital' is enacted within the business constructs, they do not make a difference.

As a method more than a theory, this requires a sensitivity in pursuing the landscape relations (eg. plant materiality, cultivation methods, desires, activities, land use policies) - involved in a business construct, and to outline the differences in the rural perceptions and to pay attention to effects of their ways of engaging with the local community-landscape itself. Hence, in the following analysis we investigate how landscapes are enacted, created and re-reshaped through the entrepreneurial activities. Specifically, we explore how it is possible to unfold the notion of the rural character of a business and consider the effects of actor-relations that might make them 'rural'.

\section{Cider and wine production: Re-configuration of farm traditions}

The physical interaction with plants, the growing and cropping of apple trees and vines, the pressing of fruits into beverages and the management of fermentation processes describe the daily activities of the cases of cider and wine production in Lincolnshire and on Funen. Together, these afford a rural character to the businesses. In each case, the entrepreneurs also purchased additional land from other local famers, thus integrating themselves into local land-based community networks.

Skidbrooke Cider is managed by one person with a young assistant, producing 1,000 litres of apple juice and 20-30,000 litres of cider per week for wholesale and supplies to local pubs. It is housed in a row of traditional farm barns attached to the family house and, besides the eye-catching stainless steel fermentation tanks, the structure of the building fulfils the idyllic image of rural life with its local brick construction. The start-up in 2004 was inspired by the owner seeing wasted apples from an old orchard and then beginning a local community initiative to gather the apples in return for some of the cider. Explaining his motivation, he said:

"You can't really get decent cider in Lincolnshire and there was such a lot of wasted fruit - there were three orchards with more than 100 trees and it was just rotting so we were just taking something that people didn't want and turning it into something that they wanted".

The entrepreneurial opportunity arose from a combination of the desire for the use of waste apples and the rural community's will to support the enterprise. Further emphasising the 'rural-ness' of the venture, pictures of the annual wassailing festival (a celebratory ritual giving thanks to the apple trees) are displayed in the barn-shop. Of course, as Lincolnshire does not have a heritage of cider production, one could argue that this is a newly invented "tradition" for the local area. Nevertheless, due to the broader cultural heritage and dominant representations of the 'rural idyll', it sits easily in the predominantly agricultural landscape and community. 
Originating from Somerset, a traditional cider producing area of England, the owner was familiar with the process but still relied on extensive advice networks, including online forums with contacts in the USA and mainland Europe. Combining these external connections with his local embeddedness, he acts as a conduit for the integration of external knowledge into local networks.

"....just on the internet we talk to each other and exchange ideas and things. That's people in the US, Europe all over but mainly for me its people in the UK, Somerset, Dorset and Southampton. For example, I'll say so-and-so has happened, what do you think it is? Or "where can you get 500 or so bottles?" it's a good group. You have to be a bit more careful about telling people how much your wholesaling litres for though"

Nyholmgaard vineyard was founded by a Danish couple in 2007 whose investment was inspired by the wish for a new lifestyle, spending as much of their daily work life outside as possible and choosing not to have employees, as they had in their former city life. They explained:

"We didn't know anything about wine growing. We haven't been to wine tastings and we never travelled around in the world to visit wineries. It was the call for doing something else. We saw a programme on television about a Danish winery that got a silver medal... and we thought, if they can... so can we!"

As they began to establish the enterprise, with such limited experience in the physical, rural aspects of the business, they had to seek out information and training - and with wine-growing such a small niche in Denmark, this relied on external contacts. They commented; "We have seen a lot of YouTube movies. When we started growing vines, we participated in a two-day course in a winery association".

Despite a self-taught, amateurish approach, the first harvests yielded silver and bronze medals in international food contests in London, followed by a broad attention on their wines from television and gourmet restaurants. This led to an immediate stabilising of the business network, as the medals acted as mediators of quality attracting local chefs and tourists to their products. Inspired by this early success, the entrepreneurs established wine-tastings, vineyard tours and a farm-shop to complement their product offering.

\section{$\underline{\text { Reinventing traditional farm landscapes - between global knowledge and local practices }}$}

The cider and wine producers are changing the local rural landscapes from fields covered by cereal crops into apple-orchards and straight lines of trellised vines. In the case of cider production this is importing an old English rural heritage to a new locality, whereas wine production in the Danish climate is regarded as something quite exotic and challenging. Changing wind directions and temperatures throughout the year are common features of both regions leading to further treeplanting to create windbreaks in the landscape. Within these new sheltered enclosures 'half-standard' apple trees and approved varieties of vines are imported and grown, developed over many years of breeding processes funded by national agricultural ministries to produce varieties adjusted to efficient harvesting and EU production standards. Although cider and wine are labelled as local products, it is apparent that a series of non-local and non-human actors are participating in their production (See Figure 2). Furthermore, the local communities are engaged in the business constructs as consumers 
of the products and as beneficiaries of the enhanced local reputation and representational attractiveness, for example appearing in tourist brochures.

Both cider and wine producers are self-taught, picking up knowledge through the internet, social media, television and their professional networks and due to the motto 'learning by doing'. Such an approach to entrepreneurial learning places an emphasis on critical moments and the need for valuable networks to support entrepreneurs' business development (Cope and Watts, 2000). Arguably we see rural skills and former local practices transformed into new versions of rurality as a result of this learning within diverse rural-urban and global-local network interactions, emphasising the complexity of categorising rural-ness.

\section{INSERT FIGURE 2 NEAR HEAR}

(the wine bottle-actors)

Text to Figure 2: The complexity of the urban and rural, global and local networks related to the production of a bottle of wine, illustrated by the many actors - human and non-human - involved in the business of Nyholmgaard vineayrd.

\section{Craft gallery and Micro Folk High School: Different perceptions of landscape and cultural values}

The copywriter/gallery and the Micro Folk High School are located in relatively isolated rural areas surrounded by manorial/estate landscapes featuring open irregular fields following the contours of the land and divided by hedgerows, areas of woodland and impressive solitary trees several hundred years old. The landscapes, nominated as 'areas of outstanding natural beauty' (UK) or regulated by conservations with specific guidelines for the cultivation (Denmark) are part of their business concepts, enacting aesthetic landscape values in their activities.

\section{The copywriter and gallery}

This conjoint business is based in a converted barn with a retail arts and crafts gallery on the ground floor and private office space upstairs for the owner's second copywriting business. The copywriting business employs two staff locally as well as other free-lancers in London and Leeds while the gallery employs 3-4 young people to cover weekends, providing good opportunities for work experience in the local community. Copywriting for urban customers is the basic activity creating the economic stability, but the passion for arts and crafts and the landscape surrounding them had led to the idea of running a workshop, presented on the website as:

"A lifelong passion for arts and crafts, salvage and retail has been realised by the building of [the premises], our rural business idyll in the 'Area of Outstanding Natural Beauty' in the Lincolnshire Wolds. A unique blend of working yard, antiques and salvage, offices, art gallery with workshops and boutique accommodation, it's the sort of place I would travel miles to shop, visit and stay. Let's hope others do too!"

Attached to the gallery is a small cottage with a panoramic view over the open cultivated fields of The Wolds. The first floor guest-suite is designed with an old-fashioned bathtub standing directly in front of a large window as a mediation between the visitor and the landscape. Demonstrating her awareness of the role of economic activity in creating this landscape, the owner explained: 
"It's an agri-landscape, it's not like your looking out onto something that's untouched, it's a working landscape - and this to us is very important."

The entrepreneur also encountered difficulties resulting from the different perceptions of local people. For example, she commented that other local rural businesses are less familiar with paying for services like PR and copywriting:

"None of my clients were from Lincolnshire, they [the local people] don't want to pay... they don't value branding and marketing I'm afraid."

Instead ten jobs have been created in other cities, and social media is her business lifeline. However, as she becomes more integrated into the local area she now employs a local apprentice, recognising that compromises may be needed for her to respond to the different demands and expectations of local businesses. Moreover, she hopes that building new networks locally can also encourage local businesses to become more aspirational.

The Micro High School emerged by the encounter between a photographer and an art historian/psychotherapist creating a new school-concept for artists and professionals situated in a clearing in the woods. With many years of professional academic experience they share a common aim of promoting the existential aspects of life and human-nature relations. Through courses in the Micro Folk High School, they offer participants new personal insights improving their abilities to perform in their daily professional lives. The courses contain humanistic leadership, photography and a mix of both activities attracting business leaders, judges, professional and amateur photographers from all over Denmark.

An old and carefully renovated forest cottage is rented from a nearby manor-house and constitutes the physical frame around the courses, as well as the surrounding manorial landscape which is directly implemented in the course activities. The couple have extensive experience and professional capacities and networks across Denmark and internationally but they have no aim of expansion:

"The micro is essential for the activities in this school. The intimacy is very important, to provide the being on a micro-level, because that's where you find new possibilities. That reflects, that we don't want to be 'macro'. We want to grow through new insights - not in the common sense of growth. In my point of view, the notion of growth is being abused politically these years... nothing can ever be big enough!"

The photographer uses the physical landscapes, both actively during the courses and as an environment for artistic inspiration. During self-development courses the participants are walking around in the woods "reaching a state of concentration that wouldn't be possible within a traditional business centre". The photographer explained,

"The landscape is not necessarily something that is finished out there; it is something one can create. It can be varied infinitely... and this is something I will discuss with the participants."

Besides course activities taking place in the small cottage the photographer also arranges photo exhibitions in the nearby town of Kerteminde, featuring contributions from amateur photographers alongside well known artists. Landscape development and changes brought about through human impacts like agriculture or pollution are the central aspects of these exhibitions which facilitate a public 
awareness of the different attitudes that exist between people with various appreciations of the aesthetical and economic dimensions of landscape uses.

\section{Enacting rural aesthetics}

The gallery and the Micro folk high school provide clear examples of different ways of engaging with landscape heritage values, and their neighbours and as they assign their local environment with different forms of appreciations and through that they are co-producers of the local heritage (Braaksma et al., 2016). The creative and philosophical interactions with rural landscapes are forms of relations enacted by business activities such as workshops and course activities that draw upon the landscapes they are located in. Professional academic skills form the basis of the business concepts in a co-production with the landscape context owned, maintained and regulated by national policies, agricultural institutions and landed estates.

As the Micro folk high school depends on the surrounding landscape for its inspirational capacity whilst also renting from the owner of the manor-house who sustains the landscape, it can be argued, that the school is intertwined in the business concept of the manor-house and that the landscapes and not merely an externality of agricultural production (Callon, 1999). The gallery owner and copywriter, however, is more focused on the economic potential of the rural landscape. Understanding non-local perceptions of rurality, she recognises a landscape value that is appreciated by outsiders who visit and are drawn to her enthusiastic portrayal of an idyllic rural. These diverse networks allow her to generate capital from the landscape in ways that local people might not be so quick to identify. contrast, trying to sell copywriting and marketing services from her urban world to a rural audience encountered very different barriers where the norms of rural cultural traditions were more difficult to assimilate compared to the hegemonic norms associated with natural or landscape assets.

\section{Chapel Studios and Film Funen: combining landscape and cultural production}

The "Film Funen" company and "Chapel Studio" are examples of business activities facilitating artists within film and music production drawing on both landscape assets and rural culture and communities. The entrepreneurs behind the two companies have careers rooted in the metropolises of Copenhagen and London, but each has subsequently moved to a quieter rural lifestyle with their families outside the stressful and noisy city life, described by the studio-owner as "the life you have, when you are young!"

Chapel studios has been running for over 20 years in a former chapel on the edge of a very small Lincolnshire village. With no close neighbours to disturb and excellent acoustics it is perfect for music recording. The studios are rented out to musicians fully equipped with recording equipment and a technical assistant for a few days or, as with the band present at the interview, for residential periods of up to five weeks. There is also a house next to the studios where bands can stay as part of the package.

The technician explained that, 
"Bands are more relaxed and more focused... the ability to go out and take in the scenery and things... it's better that just going out from a dingy city studios for a Greggs or a Subway!" [Referring to the ubiquitous national sandwich shop chains]

The local pub was also an essential link in the local business networks, especially collaborating with the farmer who cultivates the surrounding landscapes and the walking trails with famous musicians enjoying the opportunity to relax, relatively incognito, over an evening beer while a few of the other local residents were also able to enjoy a few rare moments of star-spotting. Sadly, the closure of the pub has taken away a valuable link here, reiterating the vulnerability of these sparse rural business networks. He was disappointed that pub had closed as this has taken away a key asset for his businesses. He felt that he also contributed to the local community having interesting bands visiting the pub!

\section{Insert Figure 3 here (photo from Chapel studio)}

Film Funen is a regional funded company, supported by the Funen municipalities promoting filmmaking outside the dominant cultural centre of Copenhagen. In the last two decades there has been increasing interest among Danish film-writers for using rural landscapes and villages as a contrast to urban environments. One of the pioneers of this cultural decentralisation is a former radio host and skilled journalist, who moved with his family to Funen and manages Film Funen from a rural office, drawing on his networks locally, nationally and internationally. The film productions take advantage of lower cost in the countryside and the cooperative locals. A central philosophy requires workers and contractors associated with the set to have a Funen address in order to support local artisans, producers, hotels and restaurants serving the film set and actors.

The manager explained:

"The film writers and especially the producers love to shoot their films on Funen. That's because the whole set moves to Funen during the working process and it enables a certain focus and efficiency for the production. They are fascinated by the landscape, and harsh scenes are often compensated by soft yellow wheat fields and green forests".

Film premieres are always staged in the location (e.g. manor, barn, village, street or fisherman's house) where a film has been shot or in a local village cinema, exclusively for the local community who have the chance to meet the famous actors on the red carpet - enacting a proud spirit in the local environment.

"In the countryside, people are very interested and proud about the film productions in their environments, and they collaborate nicely - which is so different in the cities, where it's hard to manage a free setting within the busy streets. We have experienced a whole island funding the last money for a film production - as the really saw the possibilities in their island being promoted through the film."

\section{Valuing rural remoteness}


Cultural values are re-invented and re-configured through processes that enrol local actors and actresses in the performing of film productions. Aside from creating jobs and supporting other local businesses, this affects local cultural self-understanding and raises awareness of the cultural values of rural places, their landscapes and buildings. In the case of music and film productions these activities are made possible by entrepreneurial personalities with wide networks rooted in the cultural urban elite. Where local communities are engaged in co-production or informally linked to these new networks, the role of businesses in providing social fulfilment alongside economic opportunities is further revealed. Located in or drawing on rural assets the new businesses work on the basis of commodifying (Perkins 2006) aspects of remoteness, the open fields and the tranquility as profoundly contrasting features to those of the major urban markets and urban business models. This is an example of how entrepreneurs are becoming aware of how it is possible to activate the landscapes they operate within by valuing these features of the remote rural areas. In other words, as Allen (2011) describes, the landscapes as make a difference, because they are involved in the actor-network of the business concepts.

\section{Discussion - Supporting rural businesses as agents of change and continuity}

Our six cases of rural entrepreneurship are summarised in Table 1 (see below) with the implications for understanding their relationship with the rural landscapes and communities. What the cases demonstrate are, that the businesses adapt and enact landscapes in various ways, and that these landscape features are transformed into new ideas and appreciations of their rural context. Along with the business development, controversies also occur when non-traditional activities, like wine production or copywriting, are challenged by divergent views on what a rural business is or should be. Furthermore, the new businesses receive only a fraction of the over-arching rural policy support which continues to be dominated by productivity-driven conventional farming practices that are detached from the innovative activities of new rural entrepreneurs. As well as revealing the hegemony of agribusiness regimes, both in rural Lincolnshire and Funen, this highlights the complex real and perceived divides between production and consumption, rural and urban, global and local, as well as innovation and tradition. Together, these distinctions challenge the structural definitions of rural and urban, as well as the perspective of what rural growth should constitute.

(Insert Table 1 near here)

Understanding the roles that local community and landscape assets play in rural business development in order to better characterize what makes what makes these businesses 'rural' were the key objectives for this article. As seen in Table 1 our cases have identified how different forms of rural assets are enacted within the entrepreneurial initiatives to generate value and to sustain their businesses. Although each of the businesses is located in a rural area, none of them focus principally on the local rural market for their trade and therefore, it is the third dimension - "sell a rural product" from the Venn diagram presented in the introduction that appears most critical in determining the rural character of these businesses. From our cases, while some of the products (e.g. local crafts, cider and wine) might be deemed typically rural, a film producer of recording studio might not. This is, however, an insufficient way of understanding the rural business activities as the outcome of artistic 
practices are equally enacting rural features - both symbolical and material - thus revealing the agency or "the power of rural" (Bell et al., 2010) of the landscapes in a new perspective.

We argue that the mutual re-configuration between the urban and rural implies an inevitable cultural and economical exchange, but that the enactment of landscape materialities make a difference between urban and rural. Scattered settlements, walking alone, waste apples, the changing images of farmland, quietness, bird life, plants, physical work with trellised vines are all crucial element in facilitating a diverse and inspiring world for rural entrepreneurs with vibrant rural places. Rural landscapes are places of inspiration, and as stated by Bell et al. (2010) "the rural also pleases us, soothing our worries through book and film and song, and rewarding our ambitions through walks, weeding and woodcutting", thus offering more than simply production or consumption spaces. Remoteness of rural life itself is found to be a quality and a positive driver for new business practices and not perceived as places to mourn about. Furthermore, the often highlighted distance parameter is turned to be a positive feature of the rural as tranquility and less populated areas are essential assets of the business concepts shown in this study. Technological devices bridge the spatial distances for knowledge exchange and customer relations and translate information into innovations of practices at a local scale, as seen in the case of invention of hot-steaming in the Danish vineyard, to overcome the cold climate in the springtime (See Table 1).

Therefore, to return to the earlier typology, the conceptualisation of a rural business must recognise a wider range of rural assets that contribute to the reshaping of the concept of a rural business. Rather than the vague "selling a rural product", we therefore propose that this should be widened to be "drawing value from rural assets" which can include local employment, social and cultural resources and aesthetics all captured within the concept of rural landscapes. This might also encompass the rural setting as the profound motivation for the entrepreneur her/himself.

The title of our paper indicates that new business activities perform roles that bring about change in rural areas, but we also recognise that through the provision of employment, the enhancement and maintenance of landscapes and build environments, the delivery of services and the upkeep of meeting places they play key roles in the continuity of rural communities too. The maintenance of open landscapes and continuance of rural places can also become a value in itself for many rural businesses, such as the "timeless" agrarian views and peaceful settings of Lincolnshire and the inspirational manor landscapes preserved as national cultural values of Funen. Of course, these are not really stable landscapes but are being continually renegotiated and reshaped by businesses and other actors (land use policies, farming practices, nature conservation) participating in rural activities It is here that the rural entrepreneur treads a fine line in presenting a positive image of the rural while simultaneously enacting development within that rural setting. Therefore, there is a need to understand the processes that drive changes in rural landscapes (Antrop, 2005; Pinto and Kristensen, 2013; Mitchell, 2013; Korsgaard et al., 2015) and the inner logic of entrepreneurial initiatives lead us to identify new modes of ordering the rural economy. In other words, we argue, that landscapes are more than merely amenities or externalities deriving from production systems (Callon, 1999). Neither are they solely framed within eco-system services without any capability to exhibit agency in a rural economy. As seen in all our cases, rural assets need to be activated in order to create values, and here the ANT tool is especially constructive in detecting the unexpected pathways of creativity enrolling the rural assets when studying these changes (Mol, 2010; Cook, 2004). Entrepreneurs themselves also need to recognise the potential landscape values they can enact. 
Approaching the rural character by applying ANT as method to open up the "black-boxes" of the business practices has provided a viable tool to understand the interactions between heterogeneous components of both the rural and urban world as well as how global knowledge exchange can create local opportunities. Further studies to sustain these new types of 'landscape-businesses' are needed to explore how rural landscape assets can activate the rural economy and develop policies to sustain them. Especially there is a need to study the business activities diversifying from conventional agricultural production as they manage larger land areas and thus are changing the rural images and practices in more dramatically way than seen in the six cases here.

\section{Conclusions}

The cases in this study show potential for both entrepreneurs and rural communities to reveal new rural economic agendas. The open landscape becomes a central actor and mediator for emerging businesses as it embodies the very difference to the urban locations. This creates a new interplay between agricultural and non-agricultural values attached to rural landscapes and these landscapes can influence new business innovations related to the multifunctionality of rural resources (Lefebvre et al., 2015; Korsgaard et al., 2015; Pinto-Correia and Kristensen, 2013).

The six business models analysed in this paper are expressly different to the anything that the highpressured, high price, urban setting can offer and therefore rural businesses can avoid competing on the unfavourable, urban-economy terms but instead provide unique services, tailored to their rural context. Through the use of technology, they are able to achieve the best of both worlds - maintaining daily communication across diverse networks of customers and suppliers whilst recognising and communicating the values that await to be activated within their rural communities and landscapes. Translating this into relative stable rural business models requires rural entrepreneurs to become better at recognising these forms of value and incorporating them into the development of highervalue products and services for people living and enjoying recreation in rural areas as well as through wider-reaching supply chains. As rural areas continue to attract more counterurbanisers with extensive urban networks and experiences, and as urban-rural interdependencies grow, the opportunities to draw on these values can be expected to continue to increase. These processes are changing rural areas in many ways, socially, culturally, physically and economically, but at the same time they are building on the patterns of perceived continuity that underpin the attractiveness of rural places; namely that of a sparsely populated and relatively "natural" environment.

Before turning these findings into policy recommendations, however, we must also remember that a number of rural entrepreneurs are pursuing lifestyle goals too. This may be the maximum carrying capacity of some local rural economies and as such, we must acknowledge that the non-economic values that are generated might be just as important as employment or growth indicators. In this light, we advocate policies - and research -that seek to promote the 'rural power' (Cloke, 2015; Bell et al., 2010) in a wider sense, not narrow employment and growth-based objectives. This will look very different across different rural areas and among different types of rural businesses which makes any prescriptive policy approach almost impossible. Few rural policy strategies could have incorporated vineyards in Denmark or recording studios in remotest Lincolnshire so we need to identify the forms of value that are active agents of change and continuity through diverse business activities and formulate polices to enrich these. As demands for tranquillity and landscape values are increasingly 
demanded in an urbanised world, new economic perspectives on externalities is a first step towards renewed acknowledgement of a qualitative rural economy.

In conclusion, improved digital infrastructure and rural business support policies combined with new ways of thinking about rural planning that enable rural entrepreneurs to take advantage of new opportunities could also yield positive outcomes. Where "rural businesses", as defined herein, are drawing value from different forms of rural assets, it will be in their interests to develop sympathetically to those values that they, and their customers, cherish. Furthermore, without development permissions, a number of traditional rural businesses might become so constrained that they are forced to leave, thereby endangering an integral component of the perceived continuity of rural life. In this respect, the management of the landscape values at both a national and community level seems to be one key element in the rejuvenation of rural places by further stimulation of a multifunctional rural economy that can meet growing urban demands for rural experiences and products alongside continuing local needs.

\section{References}

Allen, C. (2011) On Actor-Network Theory and landscape. Area 43(3): 274-280

Anderson, A., Ossiechuk, E. and Illingworth, L. (2010) Rural small businesses in turbulent times; impacts of the economic downturn. The International Journal of Entrepreneurship and Innovation 11(1): 45-56

Antrop, M. (2005) Why landscapes of the past are important for the future. Landscape and Urban Planning 70: 21-34

Bell. M., Lloyd, S. and Vatovec, C. (2010) Activating the Countryside: Rural Power, the Power of the Rural and the Making of Rural Politics. Sociologia Ruralis 50(3): 205-224

Bosworth, G. (2012) Characterising rural businesses - tales from the paperman. Journal of Rural Studies 28(4): 499-506

Bosworth, G. and Somerville, P. (Eds) (2013) Interpreting rurality; multidisciplinary perspectives. Abingdon: Routledge

Braaksma P J, Jacobs M H and van der Zande A N (2016) The Production of Local Landscape Heritage: A Case Study in The Netherlands. Landscape Research 41(1): 64-78, DOI: 10.1080/01426397.2015.1045465

Callon M (1999) Actor-network theory -the market test. In Actor-network theory and after:: 181-195 (Eds) Law J and Hassard. Oxford: Blackwell Publishers

CLA (2016) Standing up for Rural Business. Briefing Note, January 2016. www.cla.org.uk

Claval, P. (2005) Reading the rural landscapes. Landscape and Urban Planning 70(1-2): 9-19

Cloke, P. (2015) Rural Life-Styles: Material Opportunity, Cultural Experience, and How Theory Can Undermine Policy. Economic Geography 72(4): 433-449 
Cloke, P. (2006) The Handbook of Rural Studies. London: Sage

Cloke, P. and Jones, O. (2001) Dwelling, place, and landscape: an orchard in Somerset. Environment and Planning A 33(4): 649-666

Cook, I. (2004) Follow the Thing: Papaya. Antipode 36(4): 642-664

Cope, J. and Watts, G. (2000) Learning by doing: An exploration of experience, critical incidents and reflection in entrepreneurial learning. International Journal of Entrepreneurial Behaviour and Research 6(3): 104-124

Defra (2015) Towards a one nation economy: A 10 point plan for boosting productivity in rural areas. DeLondon: Defra

Finke, H B. (2014) The phenomenon of Denmark's Garden: Emerging landscape businesses. Conference Proceedings. Porto: ECLAS

Galloway, L. and Mochrie, R. (2006) Entrepreneurial motivation, orientation and realization in rural economies: A study of Scotland. International Journal of Entrepreneurship and Innovation 7(3): 173183

Halfacree, K. (1993) Locality and Social Representation: Space, Discourse and Alternative Definitions of the Rural. Journal of Rural Studies 9: 23-37

Huggins, R. and Thompson, P. (2015) Culture and Place-Based Development: A Socio-Economic Analysis. Regional Studies 49(1): 130-159

Korsgaard, S., Müller, S. and Tanvig, H W. (2015) Rural entrepreneurship or entrepreneurship in the rural - between place and space. International Journal of Entrepreneurial Behavior \& Research 21 (1): 5 - 26

Latour B (1993) We have never been modern. Harvester Wheatsheaf \& Harvard University Press

Lefebvre M, Espinosa M, Paloma S, Paracchini M, Piorr A and Zasada I (2015) Agricultural landscapes as multi-scale public good and the role of the Common Agricultural Policy. Journal of Environmental Planning and Management 58(12): 2088-2112

Malecki, E J. (2003) Digital development in rural areas: potentials and pitfalls. Journal of Rural Studies 19: 201-214

McCann, P., Dijkstra, L. and Garcilazo, E. (2014) Regional and Urban Evolutions in the OECD and Europe: Pre-Crisis and Post-Crisis. Regional Studies Winter Conference Plenary Presentation.

Available at:

http://www.regionalstudies.org/uploads/conferences/presentations/Winter 2014 Plenary present ations/Philip McCann.pdf (accessed 21st April 2015)

Mitchell, C. (2013) Creative destruction or creative enhancement? Understanding the transformation of rural spaces Journal of Rural Studies 32: 375-387

Mol, A. (2010) Actor-network theory: Sensitive terms and enduring tensions. Kölner Zeitschrift für Soziologie und Sozialpsychologie 50(1): 253-269 
Moyes, D., Ferri ,P., Henderson, F. and Whittam, G. (2015) The Stairway to Heaven? The effective use of social capital in new venture creation for a rural business. Journal of Rural Studies 39(1): 1121

Newbery, R., Sauer, J., Gorton, M., Phillipson, J. and Atterton, J. (2013) Determinants of the performance of business associations in rural settlements in the United Kingdom: an analysis of members' satisfaction and willingness-to-pay for association survival. Environment and Planning $A$ 45: 967-985

North, D. and Smallbone, D. (2006) Developing Entrepreneurship and Enterprise in Europe's Peripheral Rural Areas: Some Issues Facing Policy-makers. European Planning Studies 14(1): 41-60

OECD (2006) The New Rural Paradigm. Accessed $11^{\text {th }}$ September 2015 at:

http://www.oecd.org/gov/regional-policy/thenewruralparadigmpoliciesandgovernance.htm

Perkins, H. (2006) Commodification: re-resourcing rural areas, in Cloke, Marsden \& Mooney (Eds) The Handbook of Rural Studies :278 - 291. London: SAGE

Pinto-Correia, T. and Kristensen, L. (2013) Linking research to practice:The landscape as the basis for integrating social and ecological perspectives of the rural. Landscape and urban planning 120: 248-256

Salemink, K., Strijker, D. and Bosworth, G. (2015) "Rural Development in the Digital Age: a systematic literature review on unequal ICT availability, adoption, and use in rural areas. Journal of Rural Studies. Available online: http://dx.doi.org/10.1016/j.jrurstud.2015.09.001

Slee, B. (2005) From countrysides of production to countrysides of consumption?. Agricultural Science 143: 255-265

Vasiliki, G M. (2013) Rural space (re)produced e Practices, performances and visions: A case study from an Aegean island. Journal of Rural Studies 32: 103-113

Woods, M. (2011) Rural. London: Routledge 